\title{
Water Quality Assessment of Ponds And CHARAS OF SYLHET CITY BASED ON PH, DO AND BOD
}

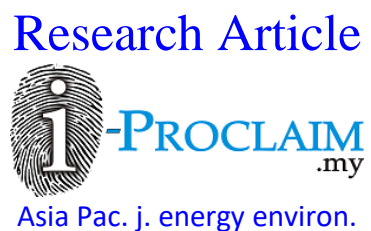

\section{Jafor Ahmed Limon', Md. Robin Sarker², Md. Naeem Hossain ${ }^{3}$}

\author{
${ }^{1}$ Senior Lecturer, Department of Civil Engineering, Leading University, Sylhet, BANGLADESH \\ ${ }^{2,3}$ Student, Department of Civil Engineering, Leading University, Sylhet, BANGLADESH \\ *Email for Correspondence: jaforlimon@gmail.com
}

Abstract

At present, the condition of surface water is much declining and the quality of water is a vital concern for mankind. It is directly linked with human security. Greater part of people is still not aware of it. So, improvement of the condition of surface water is a crying need. Surface water is often physically contaminated due to unhygienic practices. Discharges from various contaminated sources are very common thing in city life which deteriorates the water quality and necessary treatment is required to make water usable. The investigation is based on laboratory tests on water samples obtained from seven Ponds and three Charas of Sylhet City Corporation. The selected parameters for assessing the water quality are PH, Biochemical Oxygen Demand (BOD) and Dissolved Oxygen (DO). The present condition of Ponds and Charas water are not up to the mark and it is declining day by day. Proper initiatives need to take regarding the control of surface water pollution in Sylhet.

Key words

Water quality, pH, Biochemical Oxygen Demand (BOD) and Dissolved Oxygen (DO)

\section{INTRODUCTION}

Water is one of the vital components of the environment. Water covers about $70 \%$ of Earth's surface, makes up about $70 \%$ of your mass and is essential for life (www.scifun.org). With urbanization of Sylhet City, the improvement of water quality is desired. Environmental pollution has become a threat to our existence in everywhere. Water can be used for drinking, washing, swimming fishing etc. For every use, there are some standards that need to follow without which it is not eligible for use.

Many people use various sources of water. Some choose certain sources for drinking (after disinfection), recreational, drinking (after conventional treatment), fisheries, cooling industries and irrigation. Water quality is neither a static condition of a system, nor can it be defined by the measurement of only one parameter, it is variable in both time and space and requires routine monitoring to detect spatial patterns and changes over time (Geneviève and James, 2006).

Aquatic life depends on dissolved oxygen. Dissolved oxygen in streams dependents on some factors like temperature (water), aeration, breathing and decaying organisms, sediment amount and photosynthesis of plants, flow etc. $\mathrm{pH}$ is approximately the negative of the base 10 logarithm of the molar concentration, measured in units of moles per litre, of hydrogen ions (https://en.wikipedia.org/wiki/PH). According to "The Environmental Conservation Rules, 1997 (Bangladesh)", the standard pH value of surface water is 6.5 to 8.5 (The Environment Conservation Rules, 1997, Bangladesh).

Dissolved oxygen refers to the level of free, non-compound oxygen present in water or other liquids (http://www.fondriest.com/environmental-measurements/parameters/water). According to "The Environmental Conservation Rules, 1997 (Bangladesh)", the standard DO value of surface water is 5 to above (The Environment Conservation Rules, 1997, Bangladesh).

Biochemical oxygen demand ( $\mathrm{BOD}$, also called biological oxygen demand) is the amount of dissolved oxygen needed (i.e., demanded) by aerobic biological organisms to break down organic material present in a given water 
sample at certain temperature over a specific time period (https://en.wikipedia.org/wiki/Biochemical_oxygen_demand). Biochemical oxygen demand (BOD) is a measure of the amount of oxygen that bacteria will consume while decomposing organic matter under aerobic conditions (Geneviève and James, 2006). According to “The Environmental Conservation Rules, 1997 (Bangladesh)", the standard BOD5 value of surface water is 6 or less (The Environment Conservation Rules, 1997, Bangladesh).

It is important to maintain the quality of various parameters of surface water of different Charas and Ponds by regular assessment. This study does the same along with the impact of Chara water on Surma River.

\section{Study Area AND Methodology}

For this study, seven ponds and three major charas are selected. Through this selection, it has analysed the condition of the surface water of the selected ponds and charas. Ponds are Dakbanglo pond, Sheikhghat Moshjid pond, Tikorpara Akhra pond, Dostidar pond, Kajolsah pond, Policeline pond and Dhopa pond where charas are Malni chara, Guali chara and Boidha khal of Sylhet City.

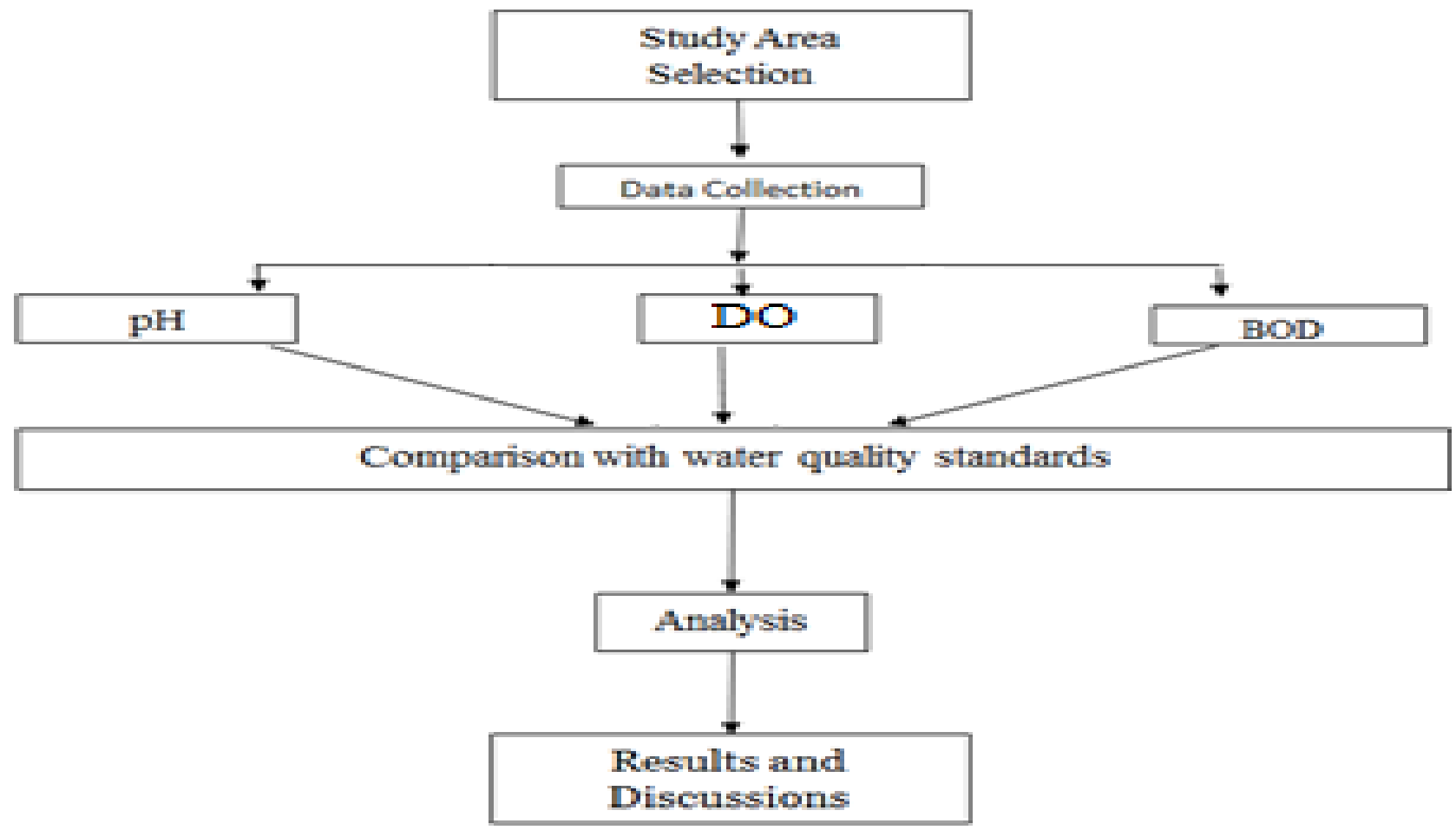

Figure 1: Working process

The study has done based on lab test for $\mathrm{pH}$, Biochemical Oxygen Demand (BOD) and Dissolved Oxygen (DO).

Table 1: Surface water quality for different purposes (The Environment Conservation Rules, 1997, Bangladesh)

\begin{tabular}{|l|l|l|l|}
\hline Practice based classification & $\mathrm{pH}$ & $\begin{array}{l}\mathrm{BOD} \\
\mathrm{mg} / 1\end{array}$ & $\begin{array}{l}\mathrm{DO} \\
\mathrm{mg} / 1\end{array}$ \\
\hline $\begin{array}{l}\text { Source of drinking water } \\
\text { for supply only after disinfecting }\end{array}$ & $6.5-8.5$ & 2 or less & 6 or above \\
\hline $\begin{array}{l}\text { Water usable for } \\
\text { recreational activity }\end{array}$ & $6.5-8.5$ & 3 or less & 5 or more \\
\hline $\begin{array}{l}\text { Source of drinking water } \\
\text { for supply, after } \\
\text { conventional treatment }\end{array}$ & $6.5-8.5$ & 6 or less & 6 or more \\
\hline Water usable by fisheries & $6.5-8.5$ & 6 or less & 5 or more \\
\hline $\begin{array}{l}\text { Water usable by various } \\
\text { process and cooling } \\
\text { industries }\end{array}$ & $6.5-8.5$ & 10 or less & 5 or more \\
\hline Water usable for irrigation & $6.5-8.5$ & 10 or less & 5 or more \\
\hline
\end{tabular}




\section{RESULTS AND Discussions}

There are lots of parameters of assessing surface water quality. Among those parameters only three of them are used to assess the quality of water (surface water). These parameters can provide some vital information on further assessment of the facts. Data has taken at Morning, Afternoon and Evening.

\section{Water quality of Ponds}

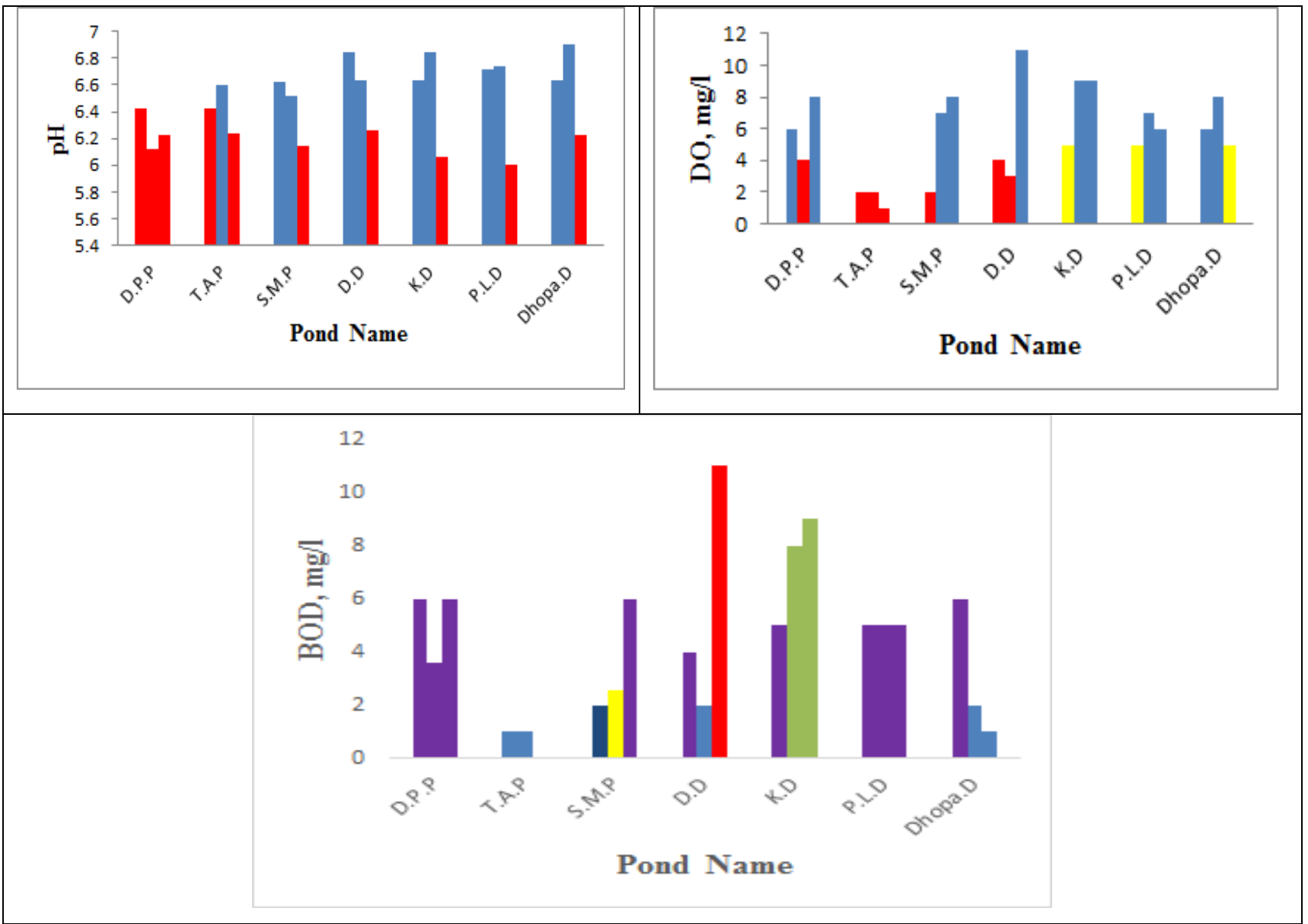

Figure 2: Water quality of Ponds

Assessment considering pH: Red bar represents that, the water is not usable while Blue bar represents usable condition for drinking (after disinfection), recreational, drinking (after conventional treatment), fisheries, cooling industries and irrigation considering the environmental conservation rules, 1997.

Assessment considering DO: Red bar represents that, the water is not usable while Blue bar represents usable condition for drinking (after disinfection), recreational, drinking (after conventional treatment), fisheries, cooling industries and irrigation considering the environmental conservation rules, 1997. Yellow bar represents that, the water is usable for recreational, fisheries, cooling industries and irrigation considering the environmental conservation rules, 1997.

Assessment considering BOD: Red bar represents that, the water is not usable while dark Blue and Blue bar represents usable condition for drinking (after disinfection), recreational, drinking (after conventional treatment), fisheries, cooling industries and irrigation considering the environmental conservation rules, 1997. Yellow bar represents that, the water is usable for recreational activity considering the environmental conservation rules, 1997. Purple bar represents that, the water is usable for drinking (after conventional treatment) and fisheries. Olive green bar represents that the water is usable for cooling industries and irrigation purposes.

The variation of the values among morning, afternoon and evening occurs because of the dumping of wastes at or near the ponds throughout the day. 
*** Other parameters along with $\mathrm{pH}, \mathrm{DO}$ and BOD needs to check before use the water for any purposes.

\section{Water quality of Malni Chara}

Table 1: Water quality of Malni-Chara

\begin{tabular}{|l|c|c|c|c|c|c|c|c|c|}
\hline & \multicolumn{9}{|c|}{ Malni-Chara } \\
\cline { 2 - 13 } & \multicolumn{3}{|c|}{ Morning } & \multicolumn{3}{c|}{ Afternoon } & \multicolumn{4}{c|}{ Evening } \\
\cline { 2 - 12 } & P-1 & P-2 & P-3 & P-1 & P-2 & P-3 & P-1 & P-2 & P-3 \\
\hline pH & 5.19 & 5.8 & 6.1 & 6.32 & 6.38 & 6.31 & 5.25 & 5.19 & 6.38 \\
\hline DO (mg/I) & 3.5 & 1 & 4.5 & 2.5 & 3 & 6 & 1.5 & 3.5 & 5 \\
\hline BOD mg/I) & 3.5 & 1 & 4.5 & 1.5 & 1.5 & 4 & 1.5 & 3.5 & 3 \\
\hline
\end{tabular}

P-1, P-2 and P-3 are the points on Chara from where samples are collected.

Table 2: Impact of Malni Chara on Surma river

\begin{tabular}{|l|c|c|c|c|c|c|}
\multirow{2}{*}{} & \multicolumn{2}{|c|}{ Morning } & \multicolumn{2}{c|}{ Afternoon } & \multicolumn{2}{c|}{ Evening } \\
\cline { 2 - 7 } & P-1 & P-2 & P-1 & P-2 & P-1 & P-2 \\
\hline pH & 5.89 & 6.23 & 6.22 & 6.1 & 5.59 & 6.1 \\
\hline DO $(\mathrm{mg} / \mathrm{I})$ & 5 & 3 & 8 & 5 & 5 & 4 \\
\hline BOD mg/l) & 4 & 1 & 8 & 5 & 5 & 4 \\
\hline
\end{tabular}

P-1 is the upstream point considering the falling point of Chara in the Surma river. P-2 is the downstream point considering the falling point of Chara in the Surma river.

Table 3: Water quality of Guali-Chara

\begin{tabular}{|l|c|c|c|c|c|c|c|c|c|}
\hline \multirow{2}{*}{} & \multicolumn{9}{|c|}{ GualiChara } \\
\cline { 2 - 12 } & \multicolumn{3}{|c|}{ Morning } & \multicolumn{3}{c|}{ Afternoon } & \multicolumn{3}{c|}{ Evening } \\
\cline { 2 - 11 } & $\mathrm{P}-1$ & $\mathrm{P}-2$ & $\mathrm{P}-3$ & $\mathrm{P}-1$ & $\mathrm{P}-2$ & $\mathrm{P}-3$ & $\mathrm{P}-1$ & $\mathrm{P}-2$ & $\mathrm{P}-3$ \\
\hline pH & 6.42 & 6.31 & 5.89 & 6.82 & 6.95 & 7 & 5.99 & 6.12 & 6.45 \\
\hline DO $(\mathrm{mg} / \mathrm{I})$ & 0 & 0 & 0 & 4 & 2 & 2 & 0 & 0 & 0 \\
\hline BOD $\mathrm{mg} / \mathrm{I})$ & 0 & 0 & 0 & 3 & 1 & 1 & 0 & 0 & 0 \\
\hline
\end{tabular}

P-1, P-2 and P-3 are the points on Chara from where samples are collected.

Table 4: Impact of Guali Chara on Surma river

\begin{tabular}{|l|c|c|c|c|c|c|}
\hline \multirow{2}{*}{} & \multicolumn{2}{|c|}{ Morning } & \multicolumn{2}{c|}{ Afternoon } & \multicolumn{2}{c|}{ Evening } \\
\cline { 2 - 7 } & $\mathrm{p}-1$ & $\mathrm{P}-2$ & $\mathrm{p}-1$ & $\mathrm{P}-2$ & $\mathrm{P}-1$ & $\mathrm{P}-2$ \\
\hline $\mathrm{pH}$ & 6.18 & 6.42 & 6.56 & 6.34 & 5.89 & 5.45 \\
\hline DO $(\mathrm{mg} / \mathrm{I})$ & 4 & 3 & 7 & 8 & 5 & 2 \\
\hline BOD $\mathrm{mg} / \mathrm{I})$ & 4 & 3 & 7 & 8 & 4 & 2 \\
\hline
\end{tabular}

P-1 is the upstream point considering the falling point of Chara in the Surma river. P-2 is the downstream point considering the falling point of Chara in the Surma river.

Table 5: Water quality of Boidha-Khal

\begin{tabular}{|l|c|c|c|c|c|c|c|c|c|}
\hline \multirow{2}{*}{} & \multicolumn{9}{|c|}{ Boidha-Khal } \\
\cline { 2 - 12 } & \multicolumn{3}{|c|}{ Morning } & \multicolumn{3}{c|}{ Afternoon } & \multicolumn{3}{c|}{ Evening } \\
\cline { 2 - 11 } & $\mathrm{P}-1$ & $\mathrm{P}-2$ & $\mathrm{P}-3$ & $\mathrm{P}-1$ & $\mathrm{P}-2$ & $\mathrm{P}-3$ & $\mathrm{P}-1$ & $\mathrm{P}-2$ & $\mathrm{P}-3$ \\
\hline $\mathrm{pH}$ & 6.2 & 6.31 & 5.89 & 6.8 & 6.91 & 6.12 & 5.98 & 6.12 & 6.45 \\
\hline $\mathrm{DO}(\mathrm{mg} / \mathrm{I})$ & 0 & 0 & 0 & 1 & 4.5 & 3 & 0 & 0 & 0 \\
\hline BOD mg/I) & 0 & 0 & 0 & 1 & 3.5 & 3 & 0 & 0 & 0 \\
\hline
\end{tabular}

P-1, P-2 and P-3 are the points on Chara from where samples are collected.

Table 6: Impact of Boidha-Khal on Surma River

\begin{tabular}{|l|c|c|c|c|c|c|}
\multirow{2}{*}{} & \multicolumn{2}{|c|}{ Morning } & \multicolumn{2}{c|}{ Afternoon } & \multicolumn{2}{c|}{ Evening } \\
\cline { 2 - 7 } & $\mathrm{P}-1$ & $\mathrm{P}-2$ & $\mathrm{P}-1$ & $\mathrm{P}-2$ & $\mathrm{P}-1$ & $\mathrm{P}-2$ \\
\hline $\mathrm{pH}$ & 5 & 5.12 & 6.12 & 6 & 5.37 & 5 \\
\hline DO $(\mathrm{mg} / \mathrm{I})$ & 5 & 7 & 8 & 5 & 6 & 4 \\
\hline BOD $\mathrm{mg} / \mathrm{I})$ & 5 & 6 & 8 & 3 & 6 & 3 \\
\hline
\end{tabular}

$\mathrm{P}-1$ is the upstream point considering the falling point of Chara in the Surma river. P-2 is the downstream point considering the falling point of Chara in the Surma river. 
Assessment considering pH: Red colour represents that, the water is not usable while Dark Blue and Blue colour represents usable condition for drinking (after disinfection), recreational, drinking (after conventional treatment), fisheries, cooling industries and irrigation considering the environmental conservation rules, 1997.

Assessment considering DO: Red colour represents that, the water is not usable while Blue colour represents usable condition for drinking (after disinfection), recreational, drinking (after conventional treatment), fisheries, cooling industries and irrigation considering the environmental conservation rules, 1997. Yellow colour represents the water that is usable for recreational, fisheries, cooling industries and irrigation.

Assessment considering BOD: Blue colour represents usable condition for drinking (after disinfection), recreational, drinking (after conventional treatment), fisheries, cooling industries and irrigation considering the environmental conservation rules, 1997. Yellow colour represents the water that is usable for Source of drinking water for supply (after conventional treatment), recreational, fisheries, cooling industries and irrigation where at the same time Purple colour represents usable condition for fisheries, source of drinking water for supply (after conventional treatment), cooling industries and irrigation.

The variation of the values among morning, afternoon and evening occurs because of the untreated waste water which comes from the houses, shops, restaurants, sewerage lines etc. throughout the day and dumping of wastage at or near the charas.

*** Other parameters along with $\mathrm{pH}, \mathrm{DO}$ and BOD needs to check before use the water for any purposes.

\section{ConCLUSION}

The paper has described the test results of the samples taken from ponds, charas and Surma River. It demonstrates that, the quality of surface water is under threat considering the surface water quality standards and the charas of Sylhet City Corporation (SCC) plays an important role to pollute the Surma river as the values of upstream (with respect to chara) and downstream (with respect to chara) parameters are different with each other.

\section{REFERENCES}

Geneviève, M. C.; James P. N. (2006). “Water Quality for Ecosystem and Human Health, United Nations Environment Programme.”

http://www.fondriest.com/environmental-measurements/parameters/water.

https://en.wikipedia.org/wiki/Biochemical_oxygen_demand.

https://en.wikipedia.org/wiki/PH.

Shakhashiri. www.scifun.org General Chemistry W ATER.

The Environment Conservation Rules, 1997, Bangladesh. 
